\title{
Cancer and occupational exposure to inorganic lead compounds: a meta-analysis of published data
}

\author{
Hua Fu, Paolo Boffetta
}

\begin{abstract}
Objectives-To review and summarise the epidemiological evidence on the carcinogenicity of occupational exposure to inorganic lead.
\end{abstract}

Methods-Case-control and cohort studies were reviewed and combined for meta-analysis. Fixed and random effect methods were used to estimate the summary effects.

Results-The combined results show a significant excess risk of overall cancer, stomach cancer, lung cancer, and bladder cancer, with relative risk ratios (RRs) and $95 \%$ confidence intervals (95\% CIs) in the meta-analysis of $1.11(1.05-1 \cdot 17)$, $1 \cdot 33(1 \cdot 18-1 \cdot 49), 1 \cdot 29(1 \cdot 10-1 \cdot 50)$, and 1.41 $(1 \cdot 16-1 \cdot 71)$ respectively. The $R R(95 \% \mathrm{CI})$ for kidney cancer was also high, but did not reach significance $(1 \cdot 19(0 \cdot 96-1 \cdot 48))$. A separate analysis of studies of heavily exposed workers provided slightly increased RRs for cancers of the stomach $(1 \cdot 50)$ and lung $(1 \cdot 42)$.

Conclusions-The findings from the workers with heavy exposure to lead provided some evidence to support the hypothesis of an association between stomach and lung cancer and exposure to lead. The main limitation of the present analysis is that the excess risks do not take account of potential confounders, because little information was available for other occupational exposures, smoking, and dietary habits. To some extent, the risk of lung cancer might be explained by confounders such as tobacco smoking and exposure to other occupational carcinogens. The excess risk of stomach cancer may also be explained, at least in part, by non-occupational factors. For bladder and kidney cancers, the excess risks are only suggestive of a true effect because of possible publication bias.

(Occup Environ Med 1995;52:73-81)

Keywords: lead; neoplasms; meta-analysis

Lead, one of the metals longest known to humans, is a major occupational toxin. Although poisoning due to occupational exposure to lead has been recognised for over 2000 years, the importance of lead in industry has led to its widespread production and use particularly for storage batteries. Whether lead is a carcinogen, however, is still not known. In 1980 and 1987, the International Agency for Research on Cancer (IARC) evaluated the evidence for carcinogenicity of lead and its compounds ${ }^{12}$ and classified lead and inorganic lead compounds as possible human carcinogens (IARC group 2B), on the basis of sufficient evidence for carcinogenicity in experimental animals but inadequate evidence for carcinogenicity in humans. Also, two epidemiological studies have focused on exposure to organolead compounds. One found a prevalence of $5 \%(7 / 139)$ for skin cancer among workers exposed to tetraethyl lead, and among non-exposed workers of $2.9 \%$ $(4 / 139){ }^{3}$ The other found excesses of respiratory cancer (observed three, SMR 1.34, $90 \%$ CI $0.82-2.05)$ and brain cancer (observed three, SMR 1.86, 90\% CI $0.51-4.82)$ in a cohort of 2510 workers who manufactured tetraethyl lead. ${ }^{4}$ Based on this inadequate evidence from human as well as animal studies, organolead compounds were placed in group 3 (not classifiable as carcinogenic to humans) by IARC. ${ }^{12}$

Insufficient statistical power is one potential reason for the inconsistent findings from epidemiological studies of occupational exposure to lead, as well as variability of type, level of exposure, and differences of study design. Although several reviews on carcinogenicity of occupational exposure to lead have appeared, ${ }^{5-7}$ none of these has provided a quantitative meta-analysis. The purpose of this review is to examine the complete scientific literature and carry out a quantitative assessment (meta-analysis) of the epidemiological results available on the carcinogenicity of exposure to lead and inorganic lead compounds (from now on referred to simply as lead).

\section{Description of previous epidemiological studies}

Exposure of workers to high concentrations of lead occurs in a variety of manufacturing processes. The principal types of primary industry with occupational exposure to lead are lead mining, smelting and refining, storage battery manufacture, welding and steel cutting, and printing. ${ }^{8}$ The highest exposure to lead occurs in the smelting and refining of the metal, where mean concentrations of lead in air can reach $4470 \mu \mathrm{g} / \mathrm{m}^{3}$. Lead oxide dust seems to be the most common hazard in the manufacture of storage batteries, with recorded mean airborne concentrations of 
Table 1 Case reports of renal tumor associated with heavy exposure to $\mathrm{Pb}$

\begin{tabular}{|c|c|c|c|c|}
\hline $\begin{array}{l}\text { Age } \\
\text { (y) }\end{array}$ & Employment & $\begin{array}{l}P b B \\
(\mu g / d l)\end{array}$ & Remarks & Reference \\
\hline 48 & $\begin{array}{l}\text { Furnace } \\
\text { tender at a } \\
\text { smelter for } \\
22 \mathrm{y}\end{array}$ & 64 & $\begin{array}{l}\text { The tumour (renal cell carcinoma) } \\
\text { contained } 2 \cdot 47 \mu \mathrm{g} \text { of lead } / \mathrm{g} \\
\text { tissue, the renal contex contained } \\
1 \cdot 07 \mu \mathrm{g} / \mathrm{g} \text {, and renal medulla } 0 \cdot 78 \\
\mu \mathrm{g} / \mathrm{g} \text { (normal adult range: } 0 \cdot 27-1 \cdot 27 \\
\mu \mathrm{g} / \mathrm{g}) \text {. }\end{array}$ & Baker et al $(1980)^{11}$ \\
\hline 61 & $\begin{array}{l}\text { In a secondary } \\
\text { lead smeltery } \\
\text { for } 34 \mathrm{y}\end{array}$ & 83 & $\begin{array}{l}\text { He had been repeatedly tested for } \mathrm{PbB} \\
\text { and treated with more } \\
\text { than five courses of chelation treatment } \\
\text { during the period of } \\
\text { employment. }\end{array}$ & Lilis $(1981)^{12}$ \\
\hline
\end{tabular}

$\mathrm{Pb}=$ lead; $\mathrm{PbB}=$ blood lead

lead from 50 to $5400 \mu \mathrm{g} / \mathrm{m}^{3} .{ }^{8}$ Exposure to lead fume occurs during high temperature ( $>$ $500^{\circ} \mathrm{C}$ ) operations such as welding or spray coating of metals with molten lead. An average lead concentration in the breathing zone of welders of structural steel has been found to be $1200 \mu \mathrm{g} / \mathrm{m}^{3}$. According to the classification by Hernberg, ${ }^{9}$ among the high risk operations are activities in which metallic lead or lead coated materials are burned and lead fumes in high concentrations are generated; these include welding, cutting of lead and lead painted constructions, spray painting, mixing of lead salt stabilisers used in the production of polyvinyl chloride plastic, mixing of crystal glass mass, sanding or scrapping of lead paint, burning of lead in enamelling workshops, and repairing of automobile radiators. Workers at moderate risk include lead miners, solderers, plumbers, cable makers, automobile repair mechanics, ship repair workers, lead founders, lead glass blowers, and pottery glaze makers.

We used Medline Express to search the scientific medical literature; epidemiological studies were found in only a few of those industries mentioned above-that is, those that involve batteries, smelting, pigment, printing, and glass. In the industries with obviously mixed exposure such as pigment, glassworks, and printing, only those studies that separated lead exposure were selected. To reduce the extent of publication bias, an

Table 2 Characteristics of the cohort studies of expsoure to $\mathrm{Pb}$

\begin{tabular}{|c|c|c|c|c|}
\hline Study population & Industry & Follow up & Exposure & Reference \\
\hline $\begin{array}{l}425 \text { Male pensioners } \\
(1926-60, \mathrm{UK})\end{array}$ & Battery & $1926-60$ & $\begin{array}{l}158 \text { Workers without exposure to } \mathrm{Pb} \\
80 \text { with light exposure, } \\
187 \text { with } \mathrm{PbU} \\
100-250 \mu \mathrm{g} / \mathrm{l}\end{array}$ & $\begin{array}{l}\text { Dingwall-Fordyce and Lane } \\
(1963)^{13}\end{array}$ \\
\hline $\begin{array}{l}1898 \text { Pensioners } \\
\text { (1644 Men and } 254 \\
\text { women), } 1925-76\end{array}$ & & $1925-76$ & $\begin{array}{l}339 \text { Workers without exposure to } \mathrm{Pb} \\
626 \text { with light exposure, } \\
933 \text { with high exposure }\end{array}$ & Malcolm and Darnett $(1982)^{14}$ \\
\hline $\begin{array}{l}2352 \text { Men } \\
\text { and }\end{array}$ & Smelter & $1946-70$ & \multirow{3}{*}{$\begin{array}{l}\text { Mean: } \mathrm{PbU} 173 \cdot 2 \mu \mathrm{g} / \mathrm{l} \text {, } \\
\mathrm{PbB} 79 \cdot 7 \mu \mathrm{g} / \mathrm{dl} ; \\
\mathrm{PbU} 129 \cdot 7 \mu \mathrm{g} / \mathrm{l} \\
\mathrm{PbB} 62 \cdot 7 \mu \mathrm{g} / \mathrm{dl} \\
\text { Same as above }\end{array}$} & \multirow[t]{2}{*}{ Cooper and Gaffey $(1975)^{15}$} \\
\hline $\begin{array}{l}4680 \text { Men } \\
(1946-70, \text { USA })\end{array}$ & Battery & $1946-70$ & & \\
\hline $\begin{array}{l}2300 \text { Men and } \\
4519 \text { Men, } \\
\text { (same as above) }\end{array}$ & $\begin{array}{l}\text { Smelter } \\
\text { Battery }\end{array}$ & $\begin{array}{l}1946-80 \\
1946-80\end{array}$ & & Cooper et al $(1985)^{16}$ \\
\hline $\begin{array}{l}1987 \text { White men employed monthly } \\
\text { for } \geqslant 1 \text { y } \\
(1940-65, \text { USA })\end{array}$ & Smelter & $1940-77$ & $\begin{array}{l}\text { Mean: airborne } \mathrm{Pb} 3.1 \mathrm{mg} / \mathrm{m}^{3} \text {, } \\
\text { (standard at the time } 0.2 \mathrm{mg} / \mathrm{m}^{3} \text { ) } \\
\mathrm{PbB} 56.3 \mu \mathrm{g} / \mathrm{dl}\end{array}$ & Selevan et al $(1985)^{17}$ \\
\hline $\begin{array}{l}1900 \text { Workers } \\
\text { (same as above) }\end{array}$ & Smelter & $1940-88$ & \multirow[t]{2}{*}{ Same as above } & Steenland et al $(1992)^{18}$ \\
\hline $\begin{array}{l}3831 \text { Men first } \\
\text { employed before } 1967 \text { for } \\
\geqslant 3 \text { months, (Sweden) }\end{array}$ & Smelter & $1950-81$ & & Gerhardsson et al $(1986)^{19}$ \\
\hline $\begin{array}{l}437 \text { Workers employed } \\
\geqslant 3 \mathrm{y} \text { at work } \\
\text { sites with high } \\
\text { exposure to } \mathrm{Pb} \text { (subcohort from above) }\end{array}$ & & & $\begin{array}{l}\text { Mean: PbB (1950) } 58.2 \mu \mathrm{g} / \mathrm{dl} \\
\mathrm{PbB}(1974) 33.6 \mu \mathrm{g} / \mathrm{dl}\end{array}$ & \\
\hline $\begin{array}{l}57 \text { Men with non-fatal } \\
\text { clinical } \mathrm{Pb} \\
\text { poisoning }(1930-45, \mathrm{UK})\end{array}$ & Pigment factory & $<1981$ & None & Davies $(1984)^{20}$ \\
\hline $\begin{array}{l}1046 \text { Men } \\
\text { employed past and } \\
\text { present at any time, } \\
(1940-69, \text { USA })\end{array}$ & $\begin{array}{l}\mathrm{Pb} \text { and } \mathrm{Zn} \\
\text { chromate pigment }\end{array}$ & $<1979$ & $\begin{array}{l}\mathrm{Pb}: \mathrm{Zn}=9: 1 \\
\text { no data on } \\
\text { exposure to } \mathrm{Pb} \text { available }\end{array}$ & Sheffet et al $(1982)^{21}$ \\
\hline $\begin{array}{l}700 \text { Compositors and } \\
460 \text { Pressmen (USA) }\end{array}$ & Printing & $1947-62$ & \multirow{3}{*}{$\begin{array}{l}\text { Oil mist in air } 5-21 \mathrm{mg} / \mathrm{m}^{3} ; \\
\text { No exposure to } \mathrm{Pb} \text { available } \\
\text { Gross ink mist } 12 \cdot 2 \mathrm{mg} / \mathrm{m}^{3} ; \\
\text { Respirable ink mist } 1 \cdot 4 \mathrm{mg} / \mathrm{m}^{3} \\
\text { No exposure to } \mathrm{Pb} \text { available } \\
\text { Job categories: } \\
\text { compositors and stereotypes; } \\
\text { photographers and photoengravers; } \\
\text { pressmen; } \\
\text { packers and forwarders; } \\
\text { others }\end{array}$} & Goldstein et al $(1970)^{22}$ \\
\hline $\begin{array}{l}1027 \text { Compositors and } \\
778 \text { Pressmen (USA) }\end{array}$ & Printing & $1958-69$ & & Pasternack and Ehrlich $(1972)^{23}$ \\
\hline $\begin{array}{l}700 \text { Workers employed for } \geqslant 5 y \\
\text { (before } 1956 \text {, Italy) }\end{array}$ & Printing & $1956-75$ & & Bertazzi and Zocchetti $(1980)^{24}$ \\
\hline \multirow{4}{*}{$\begin{array}{l}1261 \text { Male typesetters } \\
\text { (employed in } 1961, \text { USA) } \\
468 \text { Workers employed } \\
\text { for } \geqslant 1 \text { y, } \\
(1953-67 \text {, Italy) } \\
625 \text { Male art } \\
\text { glassworkers } \\
\geqslant 1 \text { month of } \\
\text { employment, } \\
(1964-1985, \text { Sweden) } \\
1803 \text { Men and } 1946 \\
\text { women, } \geqslant 3 \text { months } \\
\text { of empoyment } \\
\text { (Finland) }\end{array}$} & Printing & $1961-84$ & \multirow{2}{*}{$\begin{array}{l}12 \mu \mathrm{g} \mathrm{Pb} / \mathrm{m}^{3}, \text { in } 1942 ; \\
<10 \mu \mathrm{gb} / \mathrm{m}^{3} \text { in } 1970 \mathrm{~s} \\
\text { Producing low quality } \\
\text { glass containers }\end{array}$} & Michaels et al $(1991)^{25}$ \\
\hline & Glassworks & $<1985$ & & Cordioli et al $(1987)^{27}$ \\
\hline & Glassworks & $<1964-85$ & $0.001-0.110 \mathrm{mg} \mathrm{Pb} / \mathrm{m}^{3}$ & Wingren and Englander $(1990)^{28}$ \\
\hline & Glassworks & $1953-86$ & $\begin{array}{l}\text { Cohort was divided } \\
\text { into oral glass blowers, } \\
\text { automated glass blowers, } \\
\text { and other glass workers }\end{array}$ & Sankila et al $(1990)^{29}$ \\
\hline
\end{tabular}


Table 3 Relative risks of cancer due to exposure to $\mathrm{Pb}$ in cohort studies

\begin{tabular}{|c|c|c|c|}
\hline Reference & $\begin{array}{l}\text { Sites } \\
\text { selected }\end{array}$ & $\begin{array}{l}\text { Deaths } \\
\text { observed }\end{array}$ & $R R(95 \% C I)$ \\
\hline \multirow{11}{*}{$\begin{array}{l}\text { Battery: } \\
\text { Dingwall-Fordyce and Lane }(1963)^{13} \\
\text { Malcolm and Barnett }(1982)^{14} \ddagger \\
\text { Battery and smelter: } \\
\text { Cooper and Gaffey }(1975)^{15}\end{array}$} & & & \\
\hline & $\begin{array}{l}\text { All } \\
\text { All }\end{array}$ & $\begin{array}{r}34 \\
157\end{array}$ & $\begin{array}{l}1.19(0.8-1 \cdot 11) \\
0.98(0.83-1.15)\end{array}$ \\
\hline & & & \\
\hline & In battery: & & \\
\hline & All & 186 & $1 \cdot 11(0 \cdot 96-1 \cdot 28)$ \\
\hline & $\begin{array}{l}\text { Digestive } \\
\text { Respiratory }\end{array}$ & $\begin{array}{l}70 \\
61\end{array}$ & $\begin{array}{l}1.23(0.96-1.53) \\
1.32(1.01-1.67)\end{array}$ \\
\hline & Urinary & 5 & $0.52(0.16-1 \cdot 13)$ \\
\hline & $\begin{array}{l}\text { In smelter: } \\
\text { All }\end{array}$ & 69 & $1.33(1.04-1.68)$ \\
\hline & Digestive & 25 & $1.50(0.96-2 \cdot 16)$ \\
\hline & Respiratory & 22 & $1.48(0.93-2.19)$ \\
\hline & Urinary & 5 & $1.79(0.55-3.94)$ \\
\hline \multirow[t]{8}{*}{ Cooper et al $(1985)^{16} \ddagger$} & In battery: & & \\
\hline & $\begin{array}{l}\text { All } \\
\text { Stomach }\end{array}$ & $\begin{array}{r}344 \\
34\end{array}$ & $\begin{array}{l}1.13(1.02-1 \cdot 26) \\
1.68(0 \cdot 16-2 \cdot 35)\end{array}$ \\
\hline & Lung & $\begin{array}{r}34 \\
109\end{array}$ & $1 \cdot 24(1.02-1.50)$ \\
\hline & Kidney & 3 & $0.41(0.09-1 \cdot 21)$ \\
\hline & In smelter: & & \\
\hline & All & 120 & $1.13(0.94-1 \cdot 36)$ \\
\hline & $\begin{array}{l}\text { Stomach } \\
\text { Lung }\end{array}$ & $\begin{array}{r}9 \\
41\end{array}$ & $\begin{array}{l}1.46(0.67-2.78) \\
1.25(0.89-1.69)\end{array}$ \\
\hline & Kidney & 2 & $0.75(0.09-2.70)$ \\
\hline \multirow{12}{*}{$\begin{array}{l}\text { Smelter: } \\
\text { Selevan } \text { et al }(1985)^{17}\end{array}$} & & & \\
\hline & All & 116 & $0.95(0.69-2.49)$ \\
\hline & Digestive & 30 & $0.77(0.52-1.10)$ \\
\hline & Respiratory & 41 & \\
\hline & $\begin{array}{l}\text { Urinary } \\
\text { Kidney }\end{array}$ & $\begin{array}{r}12 \\
6\end{array}$ & $\begin{array}{l}1.69(0.87-2.95) \\
2.04(0.75-4.44)\end{array}$ \\
\hline & Bladder & 6 & $1 \cdot 44(0.53-3 \cdot 14)$ \\
\hline & In subcohort ${ }^{\star}$ : & & \\
\hline & & 72 & $1.04(0.81-1 \cdot 31)$ \\
\hline & $\begin{array}{l}\text { Digestive } \\
\text { Respiratory }\end{array}$ & 17 & $0.77(0.45-1 \cdot 23)$ \\
\hline & & $\begin{array}{r}25 \\
8\end{array}$ & $\begin{array}{l}1.20(0.78-1.77) \\
1.99(0.86-3.94)\end{array}$ \\
\hline & Kidney & 5 & $3.01(0.98-7.03)$ \\
\hline & Bladder & 3 & $1 \cdot 27(0 \cdot 26-3 \cdot 71)$ \\
\hline \multirow[t]{9}{*}{ Steenland et al $(1992)^{18} \ddagger$} & All & 192 & $0.98(0.84-1 \cdot 12)$ \\
\hline & Stomach & 15 & $1.36(0 \cdot 75-2 \cdot 24)$ \\
\hline & Lung & 72 & $1 \cdot 18(0.92-1 \cdot 48)$ \\
\hline & Kidney & 9 & $1.93(0.88-3.67)$ \\
\hline & $\begin{array}{l}\text { Bladder } \\
\text { In subcohort: }\end{array}$ & 9 & $1.93(0.88-3.67)$ \\
\hline & All & 137 & $0.98(0.81-1 \cdot 15)$ \\
\hline & Stomach & 10 & $1.28(0.61-2 \cdot 34)$ \\
\hline & Lung & 49 & $1 \cdot 11(0 \cdot 82-1 \cdot 47)$ \\
\hline & $\begin{array}{l}\text { Kidney } \\
\text { Bladder }\end{array}$ & $\begin{array}{l}8 \\
6\end{array}$ & $\begin{array}{l}2.39(1.03-4 \cdot 71) \\
1.33(0.48-2.90)\end{array}$ \\
\hline \multirow{6}{*}{ Gerhardsson et al $(1986)^{19} \ddagger$} & All & 270 & $1 \cdot 14(1 \cdot 01-1 \cdot 28)$ \\
\hline & Stomach & 46 & $1.43(1.05-1.91)$ \\
\hline & Lung & 90 & $1 \cdot 14(1 \cdot 01-1 \cdot 28)$ \\
\hline & $\begin{array}{l}\text { In subcohort†: } \\
\text { All }\end{array}$ & 23 & $0.87(0.55-1 \cdot 31)$ \\
\hline & Stomach & 3 & $0.95(0 \cdot 19-2 \cdot 74)$ \\
\hline & Lung & 8 & $1.60(0 \cdot 69-3 \cdot 15)$ \\
\hline Pigment: & & & \\
\hline Davies $(1984)^{20} \ddagger$ & All & 7 & $1.08(0 \cdot 42-2 \cdot 22)$ \\
\hline Sheffet et al $(1982)^{21} \ddagger$ & $\begin{array}{l}\text { Lung } \\
\text { All }\end{array}$ & $\begin{array}{r}4 \\
75\end{array}$ & $\begin{array}{l}1.45(0.39-2.71) \\
1.00(0.78-1.25)\end{array}$ \\
\hline & Stomach & 8 & \\
\hline & Lung & 31 & $1.35(0.92-1.92)$ \\
\hline $\begin{array}{l}\text { Printing: } \\
\text { Goldstein et al }(1970)^{22}\end{array}$ & & & \\
\hline Goldstein et al $(1970)^{22}$ & Lung: & 6 & mortality $=1 \cdot 17 / 1000$ \\
\hline & Pressmen & 3 & mortality $=1.07 / 1000$ \\
\hline Pasternack and Ehrlich $(1972)^{23}$ & All: & & \\
\hline & Compositors & 36 & mortality $=2 \cdot 94 / 1000$ \\
\hline Bertazzi and Zocchetti $(1980)^{24}$ & Pressmen & 20 & mortality $=2 \cdot 40 / 1000$ \\
\hline Bertazzi and Zocchetti $(1980)^{24}$ & $\begin{array}{l}\text { Entire cohort: } \\
\text { All }\end{array}$ & 51 & $1.23(0.92-1.62)$ \\
\hline & Digestive & 19 & $1.20(0.72-1.88)$ \\
\hline & Respiratory & 17 & $1.56(0.91-2.50)$ \\
\hline & Lung. & 13 & $1.48(0.79-2.53)$ \\
\hline & Compositors $\ddagger$ : & & \\
\hline & $\begin{array}{l}\text { All } \\
\text { Digestive }\end{array}$ & $\begin{array}{l}4 \\
2\end{array}$ & $\begin{array}{l}0.51(0.14-1.31) \\
0.59(0.13-2.79)\end{array}$ \\
\hline & Lung & 1 & $0.50(0.07-2.13)$ \\
\hline Michaels et al $(1991)^{25} \ddagger$ & All & 123 & $0.84(0.69-1.00)$ \\
\hline & Stomach & 5 & $0.55(0 \cdot 18-1 \cdot 28)$ \\
\hline & Lung & 37 & $0.89(0.62-1.22)$ \\
\hline & Prostrate & 14 & $1 \cdot 27(0 \cdot 69-2 \cdot 13)$ \\
\hline & Bladder & 8 & $1.51(0.65-2.97)$ \\
\hline Glassworks: & & & \\
\hline Cordioli et al $(1987)^{27} \ddagger$ & $\begin{array}{l}\text { All } \\
\text { Larynx }\end{array}$ & $\begin{array}{r}28 \\
4\end{array}$ & $\begin{array}{l}1.27(0.84-1.84) \\
4.49(1.20-11.40)\end{array}$ \\
\hline & Lung & 13 & $2 \cdot 09(1 \cdot 10-3 \cdot 60)$ \\
\hline Wingren and Englander $(1990)^{28} \ddagger$ & All & 26 & $1.16(0 \cdot 76-1 \cdot 71)$ \\
\hline & Pharynx & 2 & $9 \cdot 87(1 \cdot 21-36 \cdot 12)$ \\
\hline & Lung & 6 & $1.44(0.52-3 \cdot 11) \S$ \\
\hline Sankila et al $(1990)^{29} \ddagger$ & Men: & & \\
\hline & All & 163 & $1.00(0 \cdot 85-1 \cdot 17)$ \\
\hline & Stomach & 18 & $0.88(0.52-1.39)$ \\
\hline & Lung & 62 & $1.30(1.00-1 \cdot 67)$ \\
\hline & $\begin{array}{l}\text { Kidney } \\
\text { Bladder }\end{array}$ & $\begin{array}{l}3 \\
7\end{array}$ & $\begin{array}{l}0.73(0.15-2.14) \\
1.03(0.41-2.12)\end{array}$ \\
\hline & Women: & & \\
\hline & All & 140 & $0.78(0.66-0.92)$ \\
\hline & $\begin{array}{l}\text { Stomach } \\
\text { Lung }\end{array}$ & $\begin{array}{r}16 \\
7\end{array}$ & $\begin{array}{l}0.99(0.56-1.60) \\
1.11(0.45-2.29)\end{array}$ \\
\hline & & & \\
\hline
\end{tabular}

*High $\mathrm{Pb} /$ low other metals exposure; thigh exposure to $\mathrm{Pb}$; $\neq$ selected for meta-analysis; $\$ 95 \%$ $\mathrm{CI}$ was recalculated by present authors based on the observed deaths and the expected from original paper. effort was also made to collect unpublished papers, and one report was obtained through personal communication. ${ }^{10}$

\section{STUDIES BASED ON INDUSTRY \\ Case reports of renal tumour}

There are two case reports of renal tumours with pathological evidence related to heavy exposure to lead. ${ }^{112}$ Table 1 presents their major characteristics.

\section{Cohort studies}

Table 2 presents the characteristics of cohort studies of exposure to lead, and table 3 presents the results of these studies.

Battery industry - The manufacture of electric storage batteries is a major source of occupational exposure to lead, especially lead oxide dust. In 1963, Dingwall-Fordyce and Lane conducted a retrospective study of 425 pensioners who had been exposed to lead in several companies in England. ${ }^{13}$ A non-significant increased risk for all malignant neoplasms was found. When the subjects were divided into categories of exposure according to urinary lead concentrations, however, no trend in risk was found with increased exposure.

In an extended cohort of 1898 pensioners from four lead acid battery companies in England based on the earlier study there was no excess of deaths from all malignant neoplasms. ${ }^{14}$ An excess of observed (136) over expected (118.33) deaths from all cancer was, however, noted in men who died in service (proportionate mortality ratio (PMR) $1 \cdot 15, \mathrm{P}$ $>0.05)$. An increase in the PMR was seen with exposure to lead, with a PMR for no exposure of 1.02 , for light exposure 1.06 , and for high exposure 1.30. A more detailed analysis showed an excess of malignant neoplasms of the digestive tract among men in the group with no exposure to lead who died in service, with 21 observed against 12.56 expected deaths (PMR 1.67, $\mathrm{P}=0.009$ ). This excess mortality was almost entirely confined to the period 1963 to 1966 .

Battery plants and smelter workers-Cooper and Gaffey undertook a study of a cohort of 7032 male workers in six lead production facilities ( 2352 men) and 10 battery plants (4680 men) in the United States. ${ }^{15}$ High risks for all malignant neoplasms were found separately among the smelter workers (significant) and the battery workers (NS). There were excesses in deaths from digestive and respiratory cancers among both smelter and battery workers. Only the SMR for respiratory cancer among the battery workers was significant. Deficits of cancer of the urinary tract were seen in these two subcohorts. Attempts to relate SMRs by cause to a classification into high, medium, low, and unknown exposure to lead produced no consistent results.

In 1985, Cooper et al ${ }^{16}$ updated their previous cohort study ${ }^{15}$ to 1980 . They expanded the period of follow up from 24 to 34 years. They found a significant excess of deaths due to all malignant neoplasms among the battery workers, which was largely explained by more 
Table 4 Case-control studies of exposure to $\mathrm{Pb}$

\begin{tabular}{|c|c|c|c|c|c|c|}
\hline Study population & Exposure & Sex & $\begin{array}{l}\text { Cases } \\
(n)\end{array}$ & $\begin{array}{l}\text { OR }(95 \% C I) \\
\text { (exposed cases, } n)\end{array}$ & Remarks & Reference \\
\hline Lung cancer: & Glassworks & $\mathbf{M}$ & 5498 & $1 \cdot 7(1 \cdot 1-2 \cdot 5)(90 \% \mathrm{CI})$ & \multirow{4}{*}{$\begin{array}{l}\text { All exposure for } \\
\text { every } 10 \text { y of } \\
\text { employment } \\
\text { Exposure to } \mathrm{Pb} \\
\text { /level-decade }\end{array}$} & Wingren and Axelson $(1987)^{36}$ \\
\hline $\begin{array}{l}\text { (Sweden) } \dagger \\
\text { Population based }\end{array}$ & $\mathrm{Pb}$ compound & $\mathbf{M}$ & 3730 & $\begin{array}{l}(21) \\
1 \cdot 1(0 \cdot 9-1 \cdot 4)^{\star}\end{array}$ & & Siemiatycki $(1991)^{39}$ \\
\hline $\begin{array}{l}\text { (Canada) } \dagger \\
\text { Industry based } \\
\text { (UK) } \dagger\end{array}$ & $\begin{array}{l}\text { Non-ferrous } \\
\text { smelter }\end{array}$ & $\mathbf{M}$ & 174 & $\begin{array}{l}(326) \\
1 \cdot 3(1 \cdot 1-1 \cdot 6)\end{array}$ & & Ades and Kazantzis $(1988)^{33}$ \\
\hline $\begin{array}{l}\text { Industry based } \\
\text { (UK) } †\end{array}$ & $\begin{array}{l}\text { Battery and } \\
\text { other factories }\end{array}$ & $\mathbf{M}$ & 2073 & $\begin{array}{l}1 \cdot 1\left(\chi^{2}=6 \cdot 82\right) \\
(117) \\
0 \cdot 9(0 \cdot 8-1 \cdot 1) \\
(76)\end{array}$ & & Fanning $(1988)^{34}$ \\
\hline $\begin{array}{l}\text { Stomach cancer: } \\
\text { Population based } \\
\text { (Sweden) } t\end{array}$ & Glassworks & $\mathbf{M}$ & 5498 & $\begin{array}{l}1 \cdot 5(1 \cdot 1-2 \cdot 0)(90 \% \mathrm{CI}) \\
(44)\end{array}$ & \multirow{3}{*}{ Special for $\mathrm{Pb}$} & Wingren and Axelson $(1987)^{36}$ \\
\hline $\begin{array}{l}\text { Population based } \\
\text { (Sweden) }\end{array}$ & Glassworks & $M$ & 5498 & $\begin{array}{l}1 \cdot 7 \text { (low) }(1 \cdot 0-2 \cdot 8) \\
1.5 \text { (high) }(1 \cdot 0-2 \cdot 3)\end{array}$ & & Wingren and Axelson $(1933)^{38}$ \\
\hline $\begin{array}{l}\text { Population based } \\
\text { (Canada) } t\end{array}$ & $\mathrm{~Pb}$ compound & $M$ & 3730 & $\begin{array}{l}1.2(1 \cdot 0-1 \cdot 6)^{\star} \\
126\end{array}$ & & Siemiatycki $(1991)^{39}$ \\
\hline $\begin{array}{l}\text { Industry based } \\
\text { (USA) }\end{array}$ & Battery & $M$ & 30 & $\begin{array}{l}\text { lowest } 1 \cdot 0 \\
\text { 2nd } 0 \cdot 3 \\
\text { 3rd } 1 \cdot 7 \\
\text { highest } 0 \cdot 4\end{array}$ & $\begin{array}{l}\text { Test for trend: } \\
P>0.05\end{array}$ & Cooper $(1989)^{10}$ \\
\hline $\begin{array}{l}\text { Industry based } \\
\text { (UK) } \dagger \\
\text { Bladder cancer: }\end{array}$ & $\begin{array}{l}\text { Battery and } \\
\text { other factories }\end{array}$ & $M$ & 2073 & $\begin{array}{l}1 \cdot 3(1 \cdot 0-1 \cdot 7) \\
(31)\end{array}$ & \multirow{4}{*}{$\begin{array}{l}\text { For men, } \\
\text { adjusted by } \\
\text { cigarette smoking }\end{array}$} & Fanning $(1988)^{34}$ \\
\hline $\begin{array}{l}\text { Population based } \\
\text { (Canada) } \dagger\end{array}$ & $\mathrm{Pb}$ compound & $M+F$ & 826 & $\begin{array}{l}2 \cdot 0(1 \cdot 2-3 \cdot 5) \\
(61)\end{array}$ & & Risch et al $(1988)^{35}$ \\
\hline $\begin{array}{l}\text { Popuation based } \\
\text { (Canada) } \dagger \\
\text { Kidney cancer: }\end{array}$ & $\mathrm{Pb}$ compound & $M$ & 3730 & $\begin{array}{l}1 \cdot 3(1 \cdot 0-1 \cdot 6)^{\star} \\
(155)\end{array}$ & & Siemiatycki $(1991)^{39}$ \\
\hline $\begin{array}{l}\text { Population based } \\
\text { (Canada)t } \\
\text { Brain cancer: }\end{array}$ & $\mathrm{Pb}$ compound & $M$ & 3730 & $\begin{array}{l}1 \cdot 2(1 \cdot 0-1 \cdot 6) \\
(88)\end{array}$ & & Siemiatycki $(1991)^{39}$ \\
\hline $\begin{array}{l}\text { Population based } \\
\text { (USA) }\end{array}$ & Glassworks & $\mathbf{M}$ & 12916 & $\begin{array}{l}3 \cdot 0 \\
(8)\end{array}$ & $P<0.05$ & Mallin et al (1989) ${ }^{40}$ \\
\hline
\end{tabular}

$\star 0.1$ level of significance; $\dagger$ selected for meta-analysis.

deaths than expected from malignancies of the stomach and lung. Among the smelter workers, although there were excesses of deaths due to malignancies of all sites, the stomach, and lung, none reached significance because of small numbers. There were still deficits of deaths from malignancies of the kidney among both the battery and the smelter workers.

To attempt to evaluate the relative roles of occupational and non-occupational factors for a significant excess of deaths from stomach cancer found in the subcohort of 4519 battery workers already mentioned, ${ }^{16}$ a nested casecontrol study was carried out by Cooper et $a l .{ }^{10}$ Thirty cases and 120 controls were involved in the study. No association was detected between occupational exposure to lead and gastric cancer. Comparison of the cases and the controls based on quartiles for employment and on months of employment 10 and 20 years before death showed no trend of odds ratios (ORs) with the increasing employment period. There were more foreign people among the cases, with an OR of 1.29 $(P>0.05)$.

Smelters-To examine patterns of death in lead smelter workers, a retrospective analysis of mortality was conducted at a primary lead smelter in the United States. ${ }^{17}$ Exposures in departments with high lead and those with high lead and low other metals were determined from data obtained by an industrial hygiene survey. Overall mortality from cancer was not raised. Non-significant excesses of standardised mortality ratios (SMRs) were noted for respiratory cancer and kidney cancer. The SMR for kidney cancer in areas of high lead and low other metal exposure approached significance (SMR 3.01, 95\% CI $0.98-7 \cdot 03$ ). There was an increasing trend of SMRs for lung cancer and kidney cancer with duration of exposure. The SMRs for lung cancer and for kidney cancer in the latent period of $>20$ years were increased, although none of these excesses was significant.

Steenland et al extended the follow up of this lead smelter cohort from 1977 up to 1988. ${ }^{18}$ There were still non-significant excesses of deaths due to cancers of the stomach, lung, kidney, and bladder in the entire cohort. A significant SMR (95\% CI) of 2.39 $(1 \cdot 03-4 \cdot 71)$ for kidney cancer, however, was shown in the high exposure to lead group. A

Table 5 Meta-analysis for selected cancer sites of the studies of occupational exposure to $\mathrm{Pb}^{*}$

\begin{tabular}{|c|c|c|c|c|c|c|}
\hline Statistics & $\begin{array}{l}\text { Overall } \\
\text { cancer }\end{array}$ & $\begin{array}{l}\text { Stomach } \\
\text { cancer }\end{array}$ & $\begin{array}{l}\text { Lung } \\
\text { cancer(1) }\end{array}$ & $\begin{array}{l}\text { Lung } \\
\text { cancer (2) } \dagger\end{array}$ & $\begin{array}{l}\text { Kidney } \\
\text { cancer }\end{array}$ & $\begin{array}{l}\text { Bladder } \\
\text { cancer }\end{array}$ \\
\hline $\begin{array}{l}\text { Studies (n) } \\
\mathrm{RR} \\
(95 \% \mathrm{CI}) \\
\mathrm{P} \text { value from } \mathrm{Z} \\
\text { Homogeneity } \chi^{2}{ }_{\mathrm{h}} \\
\text { Homogeneity } \mathrm{P} \text { value }\end{array}$ & $\begin{array}{l}12 \\
1 \cdot 11 \\
(1 \cdot 05-1 \cdot 17) \\
<0.001 \\
18.48 \\
>0.05\end{array}$ & $\begin{array}{l}10 \\
1 \cdot 33 \\
(1 \cdot 18-1 \cdot 49) \\
<0.001 \\
9 \cdot 384 \\
>0.30\end{array}$ & $\begin{array}{l}15 \\
1 \cdot 24 \\
(1 \cdot 16-1 \cdot 33) \\
<0.001 \\
54 \cdot 80 \\
<0.001\end{array}$ & $\begin{array}{l}12 \\
1 \cdot 29 \\
(1 \cdot 10-1 \cdot 50) \\
<0.001\end{array}$ & $\begin{array}{l}5 \\
1 \cdot 19 \\
(0 \cdot 96-1 \cdot 48) \\
0 \cdot 11 \\
5 \cdot 17 \\
>0 \cdot 20\end{array}$ & $\begin{array}{l}5 \\
1 \cdot 41 \\
(1 \cdot 16-1 \cdot 71) \\
<0 \cdot 001 \\
3 \cdot 44 \\
>0 \cdot 30\end{array}$ \\
\hline
\end{tabular}

* All cohort and case-control studies reviewed were selected for meta-analysis except studies by Goldstein et al ${ }^{22}$ and Pasternack and Ehrlich ${ }^{23}$ due to no RR available.

t RRs $(95 \% \mathrm{CI})$ were estimated with the random effect approach. ${ }^{42}$ 
Table 6 Meta-analysis for selected cancer sites of the studies of heavy occupational exposure to Pb

\begin{tabular}{|c|c|c|c|c|c|}
\hline Statistics & $\begin{array}{l}\text { Overall } \\
\text { cancer }\end{array}$ & $\begin{array}{l}\text { Stomach } \\
\text { cancer }\end{array}$ & $\begin{array}{l}\text { Lung } \\
\text { cancer(1) }\end{array}$ & $\begin{array}{l}\text { Lung } \\
\text { cancer(2)† }\end{array}$ & $\begin{array}{l}\text { Kidney } \\
\text { cancer }\end{array}$ \\
\hline $\begin{array}{l}\text { Studies (n) } \\
\text { RR } \\
(95 \% \mathrm{CI}) \\
\mathrm{P} \text { value from } Z \\
\text { Homogeneity } \chi^{2}{ }_{h} \\
\text { Homogeneity } \mathrm{P} \text { value }\end{array}$ & $\begin{array}{l}5 \\
1 \cdot 08 \\
(1 \cdot 02-1 \cdot 15) \\
<0.01 \\
3.63 \\
>0.40\end{array}$ & $\begin{array}{l}4 \\
1 \cdot 50 \\
(1 \cdot 23-1 \cdot 83) \\
<0 \cdot 001 \\
0.62 \\
>0.80\end{array}$ & $\begin{array}{l}4 \\
1 \cdot 44 \\
(1 \cdot 29-1 \cdot 62) \\
<0 \cdot 001 \\
20 \cdot 22 \\
<0.001\end{array}$ & $\begin{array}{l}3 \\
1.42 \\
(1.05-1.92) \\
0.002\end{array}$ & $\begin{array}{l}3 \\
1 \cdot 26 \\
(0 \cdot 70-2 \cdot 26) \\
0 \cdot 22 \\
4 \cdot 60 \\
>0 \cdot 10\end{array}$ \\
\hline
\end{tabular}

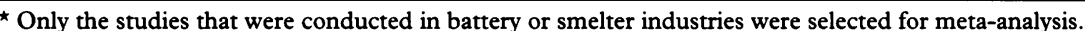

† RRs (95\% CI) were estimated with the random effect approach. ${ }^{42}$

separate analysis of this high lead group, excluding those who had ever worked in two departments with high exposure to cadmium, continued to show an excess of kidney cancer.

Gerhardsson et al conducted a retrospective cohort mortality study at a copper smelter in northern Sweden, where lead was a major airborne contaminant in the workplace. ${ }^{19}$ In the entire cohort, the overall mortality and the mortality from all malignant neoplasms were significantly increased. There were significantly high SMRs for stomach cancer and lung cancer. In the subcohort with high exposure to lead, non-significant deficits of overall mortality and of all malignant neoplasms were found. A high SMR remained only for lung cancer, but was not significant. No consistent dose-response pattern was seen when the subcohort was subdivided according to mean or peak blood lead values. The changes in SMRs for all malignant neoplasms, lung cancer, and stomach cancer were marginal when a latent period of 15 years was used for analysis.

Pigment factories-In the manufacture of lead chromate pigment, lead exposure usually occurs during the grinding or handling of the dried colours, along with exposure to chromates. Lead poisoning is often seen in workers from these factories. Davies analysed long term mortality among workers who had lead poisoning in three factories that made lead chromate pigments, which were generally based on lead nitrate produced on site from metallic lead and nitric acid..$^{20} \mathrm{~A}$ total of 57 men had non-fatal clinical lead poisoning, and among 38 deaths, seven were from cancer: four from lung cancer and one each from stomach cancer, colon cancer, and lymphatic leukaemia. The mortality from lung cancer showed a non-significant excess.

Sheffet $e t$ al conducted a cohort study in a pigment factory in Newark, NJ, USA, which produced lead chromate pigment and zinc chromate pigment. ${ }^{21}$ Deficits of overall mortality and all malignant neoplasms were found. There was, however, a significant ratio of 1.6 between observed and expected numbers of deaths resulting from lung cancer among white men. The increase in deaths from lung cancer was also significant in white men for groups employed for $\geqslant 10$ years (ratio 1:7) and for $\geqslant 2$ years with at least moderate exposure (ratio 2:1). The ratios of observed to expected numbers of deaths from stomach cancer was 2, pancreatic cancer $1 \cdot 7$, and Hodgkin's disease $2 \cdot 9$, but these were not significant. Histories on smoking were available for 14 of those who died of lung cancer: 13 smoked, nine heavily. No specific analysis for lead exposure was done.

Printing trades-Diseases related to lead have long been one of the occupational hazards of the printing trades, although the use of lead has been almost entirely eliminated in recent years with the introduction of photocomposition. Major occupational exposure to lead often occurred among compositors and stereotypers. There were many studies concerned with the mortality from cancer in printing workers, but only four dealt specifically with the occupations related to exposure to lead. Goldstein et al compared the 15 year mortality of pressmen exposed to oil mist with that of compositors in the printing industry, and found a slightly higher incidence of lung cancer in the compositors (six observed, incidence $1 \cdot 170 / 1000$ ) than in the pressmen (three observed, incidence 1.073/1000). ${ }^{22}$ Another mortality study among pressmen and compositors showed crude, non-specific death rates/1000 of 12.8 for pressmen and 14.0 for compositors and mortality from all malignant neoplasms of 2.40 for the pressmen and 2.94 for the compositors. ${ }^{23}$ Bertazzi and Zocchetti investigated the mortality of newspaper printing workers in Milan; among compositors and stereotypers there was no excess of deaths for any cause except for neoplasms of the lymphatic and haematopoietic tissue, for which an SMR of 200 was based on only one death. ${ }^{24}$ Michaels et al conducted a cohort study of newspaper printers employed at a New York Typographical Union on 1 January 1961 who were likely to have been exposed to airborne lead concentrations below the current Occupational Safety and Health Act Permitted Exposure Limit of $50 \mu \mathrm{g} / \mathrm{m}^{3} .^{25}$ Significant deficits in mortality were seen for all causes. The SMR for all malignant neoplasms was $0 \cdot 84$, a deficit that approached significance ( $95 \%$ CI upper limit of $1 \cdot 00$ ). There were non-significant excesses for cancer of the bladder and for cancer of the prostrate.

Glass manufacturing industry-The production of glass involves the use of many metals, especially lead. The production of heavy crystal glass (containing about $30 \%$ lead) and other art glasses with traditional non-mechanised techniques is an important source of occupational exposure to lead. ${ }^{26}$ The International Agency for Research on Cancer has reviewed and evaluated the risk of cancer from exposures in the glass manufacturing industry and concluded that the manufacture of art glass, glass containers, and pressed ware 
entails exposures that are probably carcinogenic to humans (group 2A). ${ }^{26}$

Cordioli and his colleagues investigated an Italian cohort of 468 workers at a plant that produced low quality glass containers. ${ }^{27}$ Significantly increased relative risk ratios (RRs) for overall cancer, lung cancer, and laryngeal cancer were found. A Swedish cohort study of 625 male art glass workers showed that mortalities from lung cancer, colon cancer, and pharyngeal cancer were in excess. ${ }^{28}$ Sankila et al studied the incidence of cancer in a cohort of 1803 men and 1946 women in two Finnish plain glass manufacturing factories. ${ }^{29}$ The risk of stomach cancer was increased in glassblowers who used oral and automated methods. For lung cancer, there was an increased risk among glassblowers who used automated methods, but not among oral glassblowers. On the other hand, an excess of skin cancer (melanomas and basal cell carcinomas excluded) among oral glassblowers was found.

Studies of proportionate mortality ratio (PMR) Of 241 male smelter workers diagnosed as having lead poisoning between 1928 and 1959 in New South Wales, Australia, 140 deaths were identified in a study of long term mortality of heavily exposed workers. ${ }^{30}$ Comparison between workers poisoned by lead and other workers showed that the standardised proportional mortality ratio (SPMR) for cancer was decreased $(0 \cdot 59)$. Another PMR study of workers exposed to lead was conducted by Cantor et al among 7121 white men; members and retirees of the United Association of Plumbers and Pipefitters in California who died in 1960-1979.31 As well as lead fumes during the sealing of cast iron pipe joints, these workers were also exposed to asbestos, polycyclic aromatic hydrocarbons (PAHs), and other hazardous materials. There were significant increases in deaths from all malignant neoplasms, stomach cancer, lung cancer, brain cancer, all lymphopoietic cancer, cancer of other lymphatic tissue, and benign neoplasms. A non-significant excess of deaths from kidney cancer was seen. Among plumbers, the PMRs for kidney cancer and lymphosarcoma or reticulosarcoma were significantly raised. Pipefitters had a significantly raised PMR for cancer, primarily due to excess lung cancer. The PMRs for other cancer sites did not show significant excesses. Deaths due to all lymphopoietic malignancies and especially "other lymphatic cancer", approached a significant excess. Finally, a proportionate cancer mortality study was conducted among employees of the United States Government Printing Office. ${ }^{32}$ An excess of deaths from multiple myeloma was confined to white workers in the composing room, where lead was the major occupational exposure.

\section{Case-control studies}

Table 4 shows the results of case-control studies based on industry.

Based on a cohort study of 4393 employees in a non-ferrous smelter where exposures to cadmium, zinc, sulphur dioxide, arsenic, lead, and dust occurred, a nested case-control study of lung cancer was conducted to identify carcinogenic effects from specific departments, processes, and contaminants. ${ }^{33}$ Among various contaminants studied, cumulative exposures to lead, as well as to arsenic, were correlated with an increased risk of lung cancer.

A study of death certificates dating back to 1926 was carried out for a total of 2073 men who were employed in several manufacturing facilities that included plastics, electrical equipment, and engineering factories as well as those producing lead acid and other batteries. Among these men, 867 who were considered to have had high or moderate levels of exposure to lead (group 1) and 1206 men with little or no exposure to lead (group 2) were chosen for a case-control study. ${ }^{34}$ For each cause of death, deaths from other causes were used as controls. There was no difference found for all malignant neoplasms between the two groups over the whole period, with an OR of 0.95 . There was, however, a clearly diminishing gradient in the ORs for cancer of the digestive tract from 1.58 in the period 1926-1945 and 1.47 in 1946-1965 to 0.97 in 1966-1985. No differences between the two groups or any sign of a secular trend were seen for other types of malignant neoplasm.

\section{COMMUNITY BASED STUDIES}

A case-control study, which included 826 histologically verified cases of urinary bladder cancer and 792 randomly selected controls from the general population, was conducted in Canada. ${ }^{35}$ The ORs for occupational exposure to 18 classes of substances were calculated. For men, a significantly increased risk was seen only for exposure to tars, asphalt, and to lead compounds. Furthermore, a significant trend in risk with duration of exposure to lead compounds was also found ( $P=$ $0 \cdot 008$ ).

Wingren and Axelson conducted a casecontrol study of risk of cancer for glassworkers in Sweden, ${ }^{36}$ based on a preliminary study in three parishes with glass industries. ${ }^{37}$ The registers of deaths and burials in a total of 11 parishes in 1950-1982 were used as the source of subjects. A moderate but significant increased $O R$ was found for glassworkers for total cancer $(1 \cdot 2 ; 90 \%$ CI $(1 \cdot 02-1 \cdot 4))$, stomach cancer $(1 \cdot 5 ; 1 \cdot 1-2 \cdot 0)$, colon cancer $(1 \cdot 6$; $1 \cdot 04-2 \cdot 5)$, and lung cancer $(1 \cdot 7 ; 1 \cdot 1-2 \cdot 5)$. A separate analysis for occupational titles showed that the highest risks for the three sites of cancer was among glassblowers. For the group of unspecified glassworkers, significantly increased risks were seen for colon cancer and lung cancer. The authors later attempted to identify certain exposures as determinants of the cancer risks. ${ }^{38}$ The risk of stomach cancer in particular was associated with exposure to arsenic, copper, nickel, manganese, and to some extent lead and chromium. For colon cancer, an increasing 
trend in risk was seen with increased use of antimony and lead. For lung cancer, no obvious trend with exposure to any metal was found.

Siemiatycki conducted a case-control study of 3730 cases with histologically confirmed cancer and completed interviews in the Montreal metropolitan area in Canada. ${ }^{39}$ From the assessment of occupational exposure to 293 substances, he found a positive association at the $10 \%$ significance level between exposure to lead compounds and cancer of the stomach, lung, bladder, and kidney after controlling for age, cigarette smoking, family income, ethnic origin, and blue or white collar occupation. A case-control study of 12916 men based on death certificates of white and black men in Illinois, USA showed a significantly high OR of 3.0 (eight cases) for brain cancer among white manufacturers of glass and glass products. ${ }^{40}$

Table 4 shows the results of the community based case-control studies.

\section{Combination of epidemiological studies}

To obtain a quantitative picture of the risk of cancer due to exposure to lead, a meta-analysis was conducted by combining the results from the analytical epidemiological studies reviewed. Attention was focused on overall cancer, stomach cancer, lung cancer, kidney cancer, and bladder cancer. Only the most recent updated studies were included if there were several studies conducted in the same population. Meta-analysis was done with the fixed effect approach described by Greenland. ${ }^{41}$ Briefly, the statistical component of a study weight, $w$, is the inverse variance computed from the estimated standard error, $\mathrm{SE}$, as $1 / \mathrm{SE}^{2}$. The weighted mean $B$ of summary effects from the study results is the weighted sum of the results, divided by the sum of the weights, $(B=\Sigma w b / \Sigma w)$. The estimate $s$ of the standard error of this mean is the inverse of the square root of the sum of the weights, $s=1 / \sqrt{\Sigma w}$. The $R R$ of the metaanalysis as the summary effects is given by $\exp (B)$ and $95 \%$ CI for the summary effects by $\exp (B \pm 1.96 \mathrm{~s})$. A rough test of whether the assumed common value is zero is given by $\mathrm{Z}=\mathrm{B} / \mathrm{s}$, which has a standard normal distribution if the assumed common value is zero. A statistical test of the homogeneity assumption is given by $\chi^{2}{ }_{h}=\Sigma w(b-B)^{2}$. When heterogeneity was indicated the random effect approach was used to estimate the summary effects (B) and its standard error (SE). ${ }^{42}$

No correction for confounders was made because there were no data available in most reports.

Table 5 summarises the results of the combination of the case-control and cohort studies except for two mortality studies that lacked an estimation of cancer risk. ${ }^{22}{ }^{23}$ After combination, there are slight to moderate but significant excess risks for all the cancer sites of interest. Bladder and stomach cancers have the highest and second highest risks; RRs obtained through meta-analyses are 1.41 $(95 \%$ CI $1 \cdot 16-1 \cdot 71)$ and $1 \cdot 33(1 \cdot 18-1 \cdot 49)$, respectively. As there was heterogeneity of the $R R$ for lung cancer across the studies, the random effect approach was used to estimate the summary effect; an RR of the meta-analysis $(95 \% \mathrm{CI})$ for lung cancer of $1.29(1 \cdot 10-1 \cdot 50)$ was obtained, compared with a fixed effect $\mathrm{RR}$ of the meta-analysis of $1 \cdot 24(1 \cdot 16-1 \cdot 33)$. The RR of the meta-analysis for kidney cancer was raised, but not significantly.

When meta-analysis was restricted to studies that were conducted in battery or smelter industries where exposure to lead was heavy, higher risks for cancers of the stomach, lung, and kidney were found compared with those in the total studies. The risk for stomach cancer increased from 1.33 to 1.50 , lung cancer (random effect model) from 1.29 to 1.42 , and kidney cancer from 1.19 to 1.22 (table 6). As there was only one study that showed any result for bladder cancer, no combined analysis was made for that.

\section{Discussion}

Although the separate epidemiological studies have yielded inconsistent results, our metaanalysis indicates that there is a significant excess of deaths from stomach cancer, lung cancer, and bladder cancer among workers exposed to lead. Exposure to lead in different industries varied greatly. It was thought that exposure levels in battery or smelter industries are much higher than those in pigment, printing, or glassworks. The analysis for the studies in the industries with heavy exposure to lead produced risks for stomach cancer and lung cancer about $20 \%$ higher than those in studies with a range of exposures. The findings further provide positive evidence to support the hypothesis that there might be higher risks for stomach cancer and lung cancer among the workers exposed to lead.

Based on the findings from experiments, Goyer raised a hypothesis on mechanisms of carcinogenesis from lead including mutagenicity, a nuclear protein effect, tumour promotion, cellular proliferation, and cystic hyperplasia induced by lead. Lead is a weak mutagen in mammalian cell systems through indirect mechanisms that include disturbances in enzyme functions that are important in DNA synthesis or repair and in the control of the DNA helical structure. ${ }^{43}$ Low concentrations of lead acetate can activate partially purified protein kinase $C$ from rat brain. This finding indicates that lead may be acting as a cocarcinogen or tumour promoter. ${ }^{44}$ Together with activation of the enzyme protein kinase $\mathrm{C}$, formation of nuclear inclusion bodies composed of a non-histone acidic protein complexed with lead may influence regulation of cellular growth and division. ${ }^{45}$ These events could constitute a basis for carcinogenesis induced by lead.

A limitation of most of the studies reviewed is a lack of data on the level of cumulative exposure to lead, as well as on potential confounders such as smoking and dietary habits, and exposure to other chemicals. Furthermore, no attempt was made in any study to identify the effects of different types 
of lead compounds. Animal experiments have indicated that some compounds (lead acetate, lead subacetate, and lead phosphate) cause tumours, whereas the evidence of carcinogenicity for others such as metallic lead and lead oxide is still inadequate. ${ }^{2}$ Another limitation of meta-analyses is publication bias, due to the fact that positive results may be more likely to be published, and the published studies may fail to mention negative results. In 14 studies with results for several sites of cancer (ignoring the case-control studies specific for a cancer site), 13 present results for lung cancer, nine for stomach cancer, five for kidney cancer, and four for bladder cancer. This could imply that the pooled results may have an overestimation of the risk of kidney and bladder cancers due to unpublished negative results; the pooled results on lung cancer, on the other hand, are less likely to have been influenced by such bias.

\section{LUNG CANCER}

Tobacco smoking is the most important cause of lung cancer, and most of the studies reviewed did not provide any information on this factor. According to an estimate by Siemiatycki et $a l,{ }^{46}$ the confounding by cigarette smoking in most occupations amounted to no more than an OR of $1 \cdot 2$, which is close to the present $R R$ from the meta-analysis for lung cancer in the total studies $(1 \cdot 29)$ but less than to that from the studies with heavy exposure to lead $(1.42)$. Therefore, it is unlikely that confounding from tobacco smoking completely explains the excess risk of lung cancer among the workers with heavy exposure to lead. One study has found that after adjustment for smoking, ethnic, and socioeconomic factors, there remained a high risk of lung cancer for exposure to lead compounds. ${ }^{39}$

In experimental studies, the risk of lung cancer due to exposure to lead might also be raised through exposure to other carcinogens. Kobayashi and Okamoto found that lead oxide, given concurrently with benzo $[a]$ pyrene by intratracheal injection, had a cocarcinogenic effect in the production of bronchoalveolar neoplasms in hamsters. ${ }^{47}$

Also, workers exposed to lead in the workplace may be simultaneously exposed to other substances such as arsenic, cadmium, and chromium, which have been confirmed to be carcinogenic. ${ }^{48}$ In a study of non-ferrous smelters, Ades and Kazantzis found that the partial correlation between arsenic and lead was particularly high. ${ }^{33}$ In glassworks, lead and arsenic have been used in the production of most kinds of art glass and exposures to them are strongly correlated. ${ }^{38}$ Gerhardsson and Nordberg determined the concentrations of antimony, arsenic, cadmium, chromium, cobalt, lanthanum, lead, selenium, and zinc in lung tissue of 85 deceased smelter workers from the same Swedish smelting plant already mentioned and 25 rural and urban controls. ${ }^{49}$ Workers who died from lung cancer had higher concentrations of antimony, arsenic, cadmium, lanthanum, and lead in the lung tissue than workers with other diseases or the rural and urban controls. Differences of cad- mium concentrations between these two groups reached significance. In contrast, the concentrations of selenium were significantly lower in the lung cancer group. These findings suggest that the cause of lung cancer among smelter workers may be multifactorial, with metals other than lead playing the major part. Compared with the other studies reviewed here, however, the risk of lung cancer in the Swedish cohort was the highest and this produced significant heterogeneity when it was included in the meta-analysis. In the primary lead smelter where the cohort study was conducted by Steenland et al, the concentrations of airborne arsenic and cadmium in the workplace were low. ${ }^{18}$ So the findings from Gerhardsson and Nordberg's study could not be representative of all situations with a high risk for lung cancer in our metaanalysis. ${ }^{49}$

\section{STOMACH CANCER}

Incidence of stomach cancer is inversely related to socioeconomic status, with an almost threefold difference between the highest and lowest categories of social class..$^{50} \mathrm{~A}$ large number of studies have confirmed the association of high risk of stomach cancer with excessive salt intake, deficient intake of fresh fruits and raw vegetables, consumption of smoked or salted meat and fish, non-centralised water supply, and infection with Helicobacter pylori. ${ }^{51} 52$ Some studies have shown that cigarette smoking increases the risk of transformation from metaplasia to dysplasia in gastric carcinogenesis. ${ }^{534}$ In the studies reviewed, none provided information on these risk factors. If the criterion of $<20 \%$ confounding by non-occupational factors is applied, ${ }^{46}$ the $R R$ of the meta-analysis of 1.33 for stomach cancer is unlikely to be entirely due to non-occupational factors, in particular the RR from the meta-analysis of $\mathbf{1 . 5 0}$ for heavy exposure to lead. The case-control study of stomach cancer among the battery workers did not detect any association of the high risk for stomach cancer with exposure to lead. ${ }^{10}$ Other occupational exposures that are suspected to be associated with risk of stomach cancer include asbestos, wood dust, nickel, chromium, and probably nitrosamines as well as some working processes. ${ }^{55}$ No clear evidence, however, suggested that workers involved in the studies reviewed had experienced exposure to such substances possibly associated with stomach cancer, although the possibility could also not be ruled out.

\section{BLADDER CANCER}

It is estimated that about $30 \%-40 \%$ of bladder cancer in men is attributable to cigarette smoking, and $10 \%-50 \%$ is due to occupational exposures. ${ }^{55}$ The best known occupational association with bladder cancer is exposure to aromatic amines. Bladder cancer is also associated with exposure to PAHs, dust, and heat risk factors. ${ }^{55}$ During metal smelting, exposure to PAHs and heat also occurs. Also, the raised RR in the metaanalysis for bladder cancer is more likely to be affected by publication bias than that of 
stomach cancer and lung cancer, because only four studies presented the results of bladder cancer in 14 studies reviewed.

\section{KIDNEY CANCER}

A non-significantly increased risk of kidney cancer was detected in the present metaanalysis. Animal experimental studies have provided convincing evidence for the induction of renal adenoma and carcinoma after oral doses of lead acetate or lead subacetate and parenteral doses of lead phosphate in rats and mice. ${ }^{2}$ Calabrese and Baldwin proposed that the enhanced susceptibility of renal epithelial cells to mitogenicity induced by lead may contribute to the carcinogenic response seen in this target organ. ${ }^{56}$ Combining these findings with an increased PMR for kidney cancer, of borderline significance, among plumbers and pipefitters ${ }^{31}$ and two cases of kidney cancer associated with heavy exposure to lead, ${ }^{112}$ the evidence is still inadequate to either confirm or rule out an association between kidney cancer and exposure to lead.

We are greatly indebted to Dr J Cheney (IARC) for his valuable review of this manuscript. This work was undertaken during the tenure of a Research Training Fellowship awarded by IARC.

1 International Agency for Research on Cancer. Some metals and metallic compounds. LARC Monogr Eval Carcinog Risks Hum 1980;23:325-415.

2 International Agency for Research on Cancer. Overall evaluation of carcinogenicity: an updating of IARC Monographs Vol 1 to 42. IARC Monogr Eval Carcinog Risks Hum 1987; update 1-42:230-2.

3 Robinson TR. Twenty year mortality of tetraethyl lead workers. $f$ Occup Med 1974;16:601-5.

4 Sweeney MH, Beaumont J, Waxweiler RJ, Halperin WE. An investigation of mortality from cancer and other causes of death among workers employed at an Eas Texas chemical plant. Arch Environ Health 1986;41: 23-8.

5 Kazantzis, G. Evaluation of the evidence for lead carcinogenicity. In: Davis, ed. Conference on environmental geochemistry and health. Cincinatti: 1989;63-79.

6 EPA. Evaluation of the potential carcinogenicity of lead and lead compounds. Washington: US Environmental Protection Agency, Office of Health and Environmental Protection Agency, Office of Health and

7 Goyer R. Lead toxicity: current concerns. Environ Health Perspect 1993;100:177-87.

8 UNEP/WHO. Lead. Geneva: United Nations Environment Programme/World Health Organization, 1977: 44-68. (Environmental Health Criteria 3.)

9 Herberg S. Principles and practical applications, part 4. Occupational medicine. Zenz C, ed. Chicago: Yearbook Medical Publishers, 1975:715-69.

10 Cooper WC, Wong O, Trent L. Case-control study of gastric cancer deaths in a lead battery plant. Report to the International Lead Zinc Research Organization. 1989.

11 Baker EL, Goyer RA, Fowler RA, Khetty U, Bernard DB, Adler $\mathrm{S}$, et al. Occupational lead exposure, nephropathy, and renal cancer. Am f Ind Med 1980;1:139-48.

12 Lilis R. Long term occupational lead exposure, chronic nephropathy, and renal cancer: a case report. $A m \mathcal{F}$ Ind Med 1981;2:293-7.

13 Dingwall-Fordyce I, Lane RE. A follow up study of lead workers. Br F Ind Med 1963;20:313-5.

14 Malcolm D, Barnett HAR. A mortality study of lead workers 1925-76. Br f Ind Med 1982;39:404-10.

15 Cooper WC, Gaffey WR. Mortality of lead workers. f Occup Med 1975;17:100-7.

16 Cooper WC, Wong O, Kheifets L. Mortality among employees of lead battery plants and lead producing plants, 1947-1980. Scand $f$ Work Environ Health plants, 1947-1980.

17 Selevan S, Landrigan PJ, Sterm FB, Jones JH. Mortality of ead smelter workers. Am f Epidemiol 1985;122:673-83.

18 Steenland K, Selevan S, Landrigan P. The mortality of lead smelter workers: an update. Am f Public Health 1992;82:1641-4.

19 Gerhardsson L, Lundstrom N-G, Nordberg G, Wall S Mortality and lead exposure: a retrospective cohort study of Swedish smelter workers. Br $\mathcal{F}$ Ind Med 1986;43. 707-12.

20 Davies JM. Long term mortality study of chromate pigment workers who suffered lead poisoning. $\mathrm{Br} \mathcal{F}$ Ind $\mathrm{Med}$ 1984;41:170-8

21 Sheffet A, Thind I, Miller AM, Louria DB. Cancer mortality in a pigment plant utilizing lead and zinc chromates. Arch Environ Health 1982;37:44-52.

22 Goldstein DH, Benoit JM, Tyroler HA. An epidemiologic study of an oil mist exposure. Arch Environ Health 1970;21:600-3.

23 Pasternack B, Ehrlich L. Occupational exposure to an oil mist atmosphere, a 12-year mortality study. Arch Environ Health 1972;25:286-94.

24 Bertazzi P, Zocchetti C. A mortality study of newspape printing workers. Am $\mathcal{f}$ Ind Med 1980;1:85-97.

25 Michaels D, Zoloth SR, Stern FB. Does low-level lead exposure increase risk of death? A mortality study of newspaper printers. Int $f$ Epidemiol 1991;20:978-83.

26 International Agency for Research on Cancer. Beryllium cadmium, mercury, and exposures in glass manufacturing industry. IARC Monogr Eval Carcinog Risks Hum ing industry. IARC

27 Cordioli G, Goughi L, Solari PL, Berrino F, Crosignani P, Riboli E. Mortality from tumours in a cohort of workers in the glass industry. Epidemiol Prev 1987;30:16-8.

28 Wingren G, Englander V. Mortality and cancer in a cohor of Swedish glassworkers. Arch Occup Environ Health 1990;62:252-7.

29 Sankila R, Kajalainen S, Pukkala E, Oksanen H, Hakulinen T, Teppo L, Hakama M. Cancer risk among glass factory workers: an excess of lung cancer? $\mathrm{Br} \mathcal{f}$ Ind Med 1990;47:815-8.

30 McMichael AJ, Johnson, HM. Long term mortality profile of heavily exposed lead smelter workers. $\mathcal{f}$ Occup Med 1982;24:375-8

31 Cantor KP, Sontag JM, Heid MF. Patterns of mortality among plumbers and pipefitters. Am F Ind Med 1986; 10:73-89.

32 Greene MH, Hoover RN, Eck RL, Fraumeni JF. Cancer mortality among printing plant workers. Environ Res 1979;20:66-73.

33 Ades AE, Kazantzis G. Lung cancer in a non-ferrous smelter: the role of cadmium. $B r \mathcal{F}$ Ind Med 1988;45: 435-42.

34 Fanning, D. A mortality study of lead workers, 1926-1985. Arch Environ Health 1988;43:247-51.

35 Risch HA, Burch JD, Miller AB, Hill GB, Steele R, Howe GR. Occupational factors and the incidence of cancer of the bladder in Canada. Br F Ind Med 1988;45:361-7.

36 Wingren G, Axelson O. Mortality in the Swedish glassworks industry. Scand $\mathcal{f}$ Work Environ Health 1987;13 412-6.

37 Wingren G, Axelson O. Mortality pattern in a glass producing factory in SE Sweden. $B r \mathcal{F}$ Ind Med 1985;42 411-4.

38 Wingren G, Axelson O. Epidemiological studies of occupational cancer as related to complex mixtures of tracer elements in the art glass industry. Scand $¥$ Work Environ Health 1993;1(suppl):95-100.

39 Siemiatycki J. Risk factors for cancer in the workplace. London: CRC Press, 1991

40 Mallin K, Rubin M, Joo E. Occupational cancer mortality in Illinoian white and black males, 1979-1984, for seven cancer sites. Am f Ind Med 1989;15:699-717.

41 Greenland S. Quantitative methods in the review of epidemiologic literature. Epidemiol Rev 1987;9:1-30.

42 DeSimonian R, Laird N. Meta-analysis in clinical trials. Controlled Clin Trials 1986;7:177-88.

43 Zelikoff $\mathrm{JT}, \mathrm{Li} \mathrm{JH}$, Hartwig A, Wang XW, Costa M, Rossman TG. Genetic toxicology of lead compounds. Carconogenesis 1988;9:1727-32.

44 Markovac J, Goldstein GW. Picomolar concentrations of lead stimulate brain protein kinase C. Nature 1988;334: $71-3$

45 Beck BD. An update on exposure and effects of lead. Fundam Appl Toxicol 1992;18:1-16.

46 Siemiatycki J, Wacholder S, Dewar R, Cardis E, Greenwood C, Richardson L. Degree of confounding bias related to smoking, ethnic group, and socioeconomic status in estimates of the association between occupational and cancer. F Occup Med 1988;30:617-25.

47 Kobayashi N, Okamoto $T$. Effects of lead oxide on the induction of lung tumors in Syrian hamsters. $f$ Natl Cancer Inst 1974;52:1605-7.

48 Boffetta P. Carcinogenicity of trace elements with reference to evaluation made by the International Agency for Research on Cancer. Scand $f$ Work Environ Health Research on Car

49 Gerhardsson L, Nordberg G. Lung cancer in smelter workers - interactions of metals as indicated by tissue levels. Scand $\mathcal{f}$ Work Environ Health 1993;19:90-4

50 Tomatis L. Cancer: causes, occurrence and control. Lyon IARC Sci Publ 1990;100.

51 Boeing $\mathrm{H}$. Epidemiological research in stomach cancer: progress over the

52 Correa P. Human gastric carcinogenisis: a multistep and multifactorial process-First American Cancer Society multifactorial process-First American Cancer Society award lecture on cancer epider

53 Fontham E, Zavala D, Correa P, Rodriguez E, Hunter F Haenszel W, Tannenbaum SR. Diet and chronic atrophic gastritis: a case-control study. $\mathcal{F}$ Natl Cancer Inst 1986;76:621-7.

54 Kneller R, You WC, Chang YS, Liu WD, Zhang L, Zhao $\mathrm{L}$, et al. Cigarette smoking and other risk factors for progression of precancerous stomach lesions. $\mathcal{F}$ Natl Cancer Inst 1992;84:1261-6.

55 Weeks J, Levy BS, Wagner GR. Preventing occupational diseases and injury. Washington: American Public Health Association, 1991 .

56 Calabrese EJ, Baldwin LA. Lead-induced cell proliferation and organ-specific tumorigenicity. Drug Metab Rev 1992;24:409-16. 